\title{
Investment Efficiency Between Listed And Unlisted Firms, And Big 4 Audit Firms’ Effect: Evidence From Korea
}

\author{
Sambock Park, Hanyang University, South Korea \\ Imhyeon Kim, Hanyang University, South Korea \\ Wooyoung Kim, Dongduk Women's University, South Korea
}

\begin{abstract}
We examine the difference in investment efficiency between listed and unlisted firms and the effects of auditing by Big 4 audit firms on the investment efficiency of firms. Generally, listed firms are large in size, have a high level of stakeholders' demands on the firm information, and show large ripple effects of managers' decision making. Listed firms have a demand hypothesis that they are motivated to provide high quality accounting information and an opportunistic behavior hypothesis that they are more motivated to make opportunistic financial reporting to meet the expectations of capital markets compared to unlisted firms. Consistent with previous study (Chen, Hope, Li \& Wang, 2011), this study measures investment efficiency using the investment forecasting model as a growth opportunity function. The results of the study, in the analysis of full samples, the listed firms have significantly higher investment efficiency than the unlisted ones. In the over-investment samples, it is found that the listed firms have higher investment efficiency. On the contrary, in the under-investment samples, indicate it is found that the unlisted firms have higher investment efficiency. Finally, it is found that listed firms audited by Big 4 audit firms have the higher investment efficiency. This study contributes to the literature on investment efficiency of listed and unlisted firms. Finally, it is expected that it will provide useful information on investment efficiency by expanding the scope of research and making the measurement of variables more precise.
\end{abstract}

Keywords: Listed Firms; Unlisted Firms; Investment Efficiency; Big 4 Audit Firms

\section{INTRODUCTION}

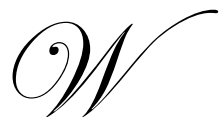

e examine the difference in investment efficiency between listed and unlisted firms and effect of auditing by Big 4 audit firms on the investment efficiency of firms. Whether firms have been listed or not affects financial reporting and managers' decision making (Beatty, Ke \& Petroni, 2002; Ball \& Shivarkumar, 2005). Generally, listed firms are large in size, have a high level of stakeholders' demands on the firm information, and show large ripple effects of managers' decision making. The pressure of stakeholder groups surrounding firms affects the quality of earnings produced by firms (Ball \& Shivarkumar, 2005; Kim \& Yi, 2006). Prior studies show that unlisted firms have lower financial reporting quality (FRQ) than do listed firms. For instance, Ball and Shivakumar (2005) find that unlisted U.K. firms recognize loss less timely than do listed firms. Burgstahler, Hail and Leuz (2006) document that unlisted firms have lower earnings quality.

In this study, we examine whether the difference in the FRQ between listed and unlisted firms are systematically related to investment decisions which is one of the most important decision of firms. When the FRQ is improved, information asymmetry decreases, which reduces the cost of capital and adverse selection costs, thereby enabling the firm to invest efficiently (Verdi, 2006). The higher FRQ has been shown to reduce both the under-investments of firms that face financial constraints and the over-investments occurring in firms that have large amounts of cash and free cash flows (Biddle, Hilary \& Verdi, 2009).

Givoly, Hayn and Katz (2010) refer that favor either listed firms or unlisted firms as having higher FRQ as demand and opportunistic behavior hypotheses. The demand hypotheses argue that the demand for higher FRQ is greater 
among listed firms. Listed firms have greater owner-manager division, greater ownership dispersion than do unlisted firms (Hope, Thomas \& Vyas, 2013). These ownership structures create asymmetric information, leading stakeholders to demand high-quality information. In contrast, the opportunistic behavior hypotheses argue that listed firms hide true performance by handling financial information. Listed firms have incentives to handle earnings due to market pressures (Graham, Harvey \& Rajgopal, 2005).

Stakeholders of listed firms have come to require high financial reporting quality on firm information because equity trading is frequent and external financial reporting is relatively more important. The incentive for a listed firm to improve the FRQ or to manage earnings is determined by comparing costs and benefits involved in each decision (Nam, 2010). Generally, listed firms are expected to have more of the costs from opportunistic behavior of managers than benefits. Due to the relatively large number of stakeholders, listed firms have large costs (firm reputation, financing, stock prices, and legal action) when opportunistic behavior is discovered. Prior studies provide the general conclusion that on average, listed firms have higher FRQ and report more conservative accounting, consistent with the demand hypothesis dominating the opportunistic behavior hypothesis.

This study has two research hypotheses. First, we examine the difference in investment efficiency between listed and unlisted firms according to the demand hypothesis and the opportunistic behavior hypothesis proposed by Givoly et al. (2010). Second, we examine the difference in investment efficiency between listed firms employing Big 4 audit firms and other firms based on previous research that the FRQ audited by a Big 4 audit firm is more excellent than that of other firms. Consistent with previous study (Chen et al., 2011), this study measures investment efficiency using the investment forecasting model as a growth opportunity function.

The results of the study, in the analysis of full samples, indicate listed firms have significantly higher investment efficiency than unlisted ones. In the over-investment samples, it is found that the listed firms have higher investment efficiency. On the contrary, in the under-investment samples, it is found that the unlisted firms have higher investment efficiency. This can be interpreted that the reduction effects of inefficient investment in listed firms is mainly caused by the suppression of over-investment. In addition, it is found that listed firms audited by Big 4 audit firms have the higher investment efficiency. This can be interpreted that the Big 4 audit firms provide high quality auditing service to provide the higher FRQ; which improves the investment efficiency of the firm. In further analysis, listed firms are classified into the KOSPI and KOSDAQ listed firms. As a result of comparing with the unlisted firms, it is found that the KOSPI listed firms have higher investment efficiency than the KOSDAQ listed firms and unlisted firms.

This study provides the following contributions. First, this study is expected to help understanding the characteristics of financial reporting provided by listed and unlisted firms by presenting empirical results on investment efficiency as under-investment and over-investment. Second, our results show that the audit by a Big 4 audit firm produces high quality accounting information and affects the improvement of investment efficiency. Finally, it is expected that it will provide useful information on investment efficiency by expanding the scope of research and making the measurement of variables more precise.

The next section describes the literature and hypotheses. Section 3 describes the empirical models, measurement of variable, and data. Section 4 provides results of the empirical tests, and section 5 concludes.

\section{PRIOR LITERATURE AND HYPOTHESES}

\subsection{FRQ of Listed and Unlisted Firms}

The pressure of stakeholder groups surrounding firms affects the quality of earnings produced by firms (Ball \& Shivarkumar, 2005; Kim \& Yi, 2006). We examine the difference in investment efficiency between listed and unlisted firms according to the demand hypothesis and the opportunistic behavior hypothesis proposed by Givoly et al. (2010).

Ball and Shivarkumar (2005) find that unlisted U.K. firms report less conservatively compared with listed firms. These results mean that unlisted firms have low demand for financial reporting. Leuz, Nanda and Wysocki (2003) depend on an earnings management measure presented by Burgstahler et al. (2006) that is based on five different measures. 
The basic measures are devised to detect all of earnings adjustment type, such as income smoothing and earnings management. They argue that unlisted firms exhibit lower accrual quality.

Nichols, Wahlen and Wieland (2009) presented empirical evidence that unlisted banks are less conservative than listed banks. This indicates that the listing status refers to the form of the capital market which the firm belongs and the FRQ varies depending on the listing status. Hope et al. (2013) document that in general unlisted firms have lower earnings quality and have less accounting conservatism. These results indicate that listed firms have higher demand for high quality financial information. Nam (2010) studies the qualitative characteristics of accounting information for listed and unlisted small business. Listed small business shows high persistence of accounting information, low degree of income smoothing, and low performance adjustment discretionary accruals. Listed small business shows that the FRQ is higher than that of unlisted small business because the demand of accounting information of stakeholders is high.

Other studies provide evidence that unlisted firms have higher accrual quality. Beatty et al. (2002) focus on earnings manipulations and use a sample of 1,160 unlisted banks and 707 listed banks. They find that relative to listed banks, unlisted banks are less likely to manage their accounting information to avoid income decrease, suggesting that accrual quality is higher in unlisted banks. Kim and Yi (2006) document that unlisted firms are less likely to manage earnings to meet stakeholder expectations, which negatively affects the FRQ. Using a sample of 531 firms, Givoly et al. (2010) find that unlisted firms have higher accrual quality, lower propensity to handle financial reporting, and higher accrual persistence than do listed firms.

\subsection{FRQ and Investment Efficiency}

As mentioned above, prior studies suggest that the FRQ can decrease information asymmetry between firms and investors. Therefore, if the information asymmetry decreases, the reverse selection costs and financing costs become lower, which makes the right decision when selecting the investment plan (Verdi, 2006). According to a study of the effects of the FRQ on capital costs, when the FRQ is higher, the financing costs are lower (Francis, LaFond, Olsson and Schipper, 2004), and investment efficiency of a firm is higher (Verdi, 2006; Biddle et al., 2009). In addition, reverse selection cost is also reduced at the time of earnings announcement (Bhattacharya, Desai \& Venkataraman, 2007).

Accruals have been found to provide useful information for predicting future cash flows. From the viewpoint of the creditor, it is difficult to estimate the future cash flow using accounting information when the accruals quality is low, so that the uncertainty about the debt repayment of the firm increases. If the future cash flow is estimated based on the accruals on the investor's side, the quality of accruals may affect uncertainty on future performance distribution of the firm, which causes asymmetric information between information and non-information investors (Bhattacharya et al. 2007). Therefore, if the borrower has low accruals quality, the cost of financing will rise and affect contracts with stakeholders.

A study of the FRQ also examined the effects of asymmetric information and agency cost on firms' cash holdings. Biddle et al. (2009) find that the FRQ reduces inefficient investments (over-investment and under-investment) in firms with a lot of cash holdings and with financial constraints. Leuz and Verrecchia (2000) also find that the FRQ improves investment efficiency and increases expected cash flow through a model that takes into account the relevance of the FRQ and cash flow. Garcia-Teruel, Martinez-Solano and Sanchez-Ballesta (2009) report that firms with higher quality of accruals have lower cash holdings than firms with lower quality of accruals. Therefore, these evidences show that FRQ can decrease asymmetric information and cost of adverse selection, which can reduce the level of cash holdings.

\subsection{Hypotheses Development}

Listed and unlisted firms have different methods of financing, dispersion of stocks (ownership structure), size of firms, and number of stakeholders. As a result, the incentives for financial reporting differ and there is a difference in the FRQ (Kwak \& Park, 2010). Givoly et al. (2010) document that favor either listed firms or unlisted firms as having higher FRQ as demand and opportunistic behavior hypotheses. The demand hypotheses argue that the demand for higher FRQ is greater among listed firms. Listed firms have greater owner-manager division, greater ownership dispersion than do unlisted firms (Hope et al., 2013). These ownership structures create asymmetric information, 
leading stakeholders to demand high-quality information. In contrast, the opportunistic behavior hypotheses argue that listed firms hide true performance by handling financial information. Listed firms have incentives to handle earnings due to market pressures (Graham et al., 2005). However, in the case of listed firms, stock trading happens frequently and the importance of external financial reporting is high. Thus, listed firm stakeholders demand high quality of accounting information.

The incentive for a listed firm to improve the FRQ or to manage earnings is determined by comparing between the costs and benefits involved in each decision (Nam, 2010). Generally, listed firms are expected to have more of the costs from opportunistic behavior of managers than benefits. Due to the relatively large number of stakeholders, listed firms have large costs (firm reputation, financing, stock prices, and legal action) when opportunistic behavior is discovered. Prior studies provide the general conclusion that on average, listed firms have higher FRQ and report more conservative accounting, consistent with the demand hypothesis dominating the opportunistic behavior hypothesis. Several previous studies have shown that the higher the FRQ, the better the investment efficiency by alleviating market friction such as reverse selection and moral hazard (Leuz \& Verrecchia, 2000; Bushman \& Smith, 2001). In other words, financial reporting is used by shareholders to keep watch on managers, and is an important source of information on firm risk for investors (Kanodia \& Lee, 1998). If qualitative financial reporting enhances shareholders' ability to keep watch managers' investment activities, it can increase investment efficiency by decreasing moral hazard. Also, if qualitative financial reporting reduces the cost of reverse selection, it can increase investment efficiency by decreasing the cost of financing and the likelihood of acquiring additional funds at misleading prices. In other words, reliable accounting information raises the monitoring level of the managers' moral hazard and positively affects the managers' investment decision. Based on the above description, we expect that listed firms to be more efficient than unlisted firms, and set the following hypotheses:

$\mathbf{H}_{\mathbf{1}}$ : Listed firms will have higher investment efficiency than unlisted firms;

$\mathbf{H}_{1 \mathbf{a}}$ : Listed firms will be less likely to make abnormal over-investments compared to unlisted firms; and

$\mathbf{H}_{\mathbf{1 b}}$ : Listed firms will be less likely to make abnormal under-investments compared to unlisted firms.

Managers make decisions that conflict with interests of shareholders to pursue their own interests (Jensen \& Meckling, 1976). Managers can distort investment decisions, one of the most important decisions in the process of pursuing their own interests. High-quality accounting information is one means of reducing the manager's moral hazard and reverse selection (Bushman \& Smith, 2001; Lambert, Leuz \& Verrecchia, 2007). Reliable accounting information reduces the reverse selection of external investors and information asymmetry between investors and firms. This prevents managers from investing in scale expansion. Biddle, (2009) investigate the effect of FRQ on each investment by dividing into under-investment and over-investment. The results show that high quality accounting information reduces both over-investment and under-investment.

DeAngelo (1981) argues that independent external auditing reduces stakeholders' information asymmetry problems. Prior studies find that firms employing Big 4 auditors have a greater quality of financial reporting (Reynolds \& Francis, 2000). In general, Big 4 audit firms have more efficient resources and expertise in performing an audit. The auditing by Big 4 audit firms (BIG4) is a constraint on managers' opportunistic and inadequate accounting in financial reporting. Therefore, listed firms employing a Big 4 audit firm are expected to have excellent financial reporting. Based on the above description, we expect that listed firms employing a Big 4 audit firm will have a greater investment efficiency than those that do not and set the following hypotheses:

$\mathbf{H}_{2}$ : Listed firms employing a Big 4 audit firm will have a greater investment efficiency than those that do not;

$\mathbf{H}_{2 \mathrm{a}}$ : Listed firms employing a Big 4 audit firm will be less likely to make abnormal over-investments than those that do not; and

$\mathbf{H}_{2 \mathrm{~b}}$ : Listed firms employing a Big 4 audit firm will be less likely to make abnormal under-investments than those that do not. 


\section{RESEARCH DESIGN}

\subsection{Empirical Models}

\subsubsection{Investment Efficiency Between Listed and Unlisted Firms}

We first test for difference in investment efficiency between listed and unlisted firms (H1) using Equation (1). Following Chen et al. (2011), we regress the model (1) separately for under-investment and over-investment. The basic model is:

$$
\begin{aligned}
& \text { InvEff }_{i t}=\beta_{0}+\beta_{1} \text { LIST }_{i t}+\beta_{2} \text { BIG }_{i t}+\beta_{3} \text { SIZE }_{i t}+\alpha_{4} \text { TANG }_{i t}+\beta_{5} \text { SLACK }_{i t}+\beta_{6} \text { OPCYCLE }_{i t}+ \\
& \beta_{7} \text { LOSS }_{i t}+\beta_{8} R O A_{i t}+\beta_{9} C \text { fo_Sales }_{i t}+\beta_{10} F R Q 1_{i t}+\beta_{11} \text { FRQ2 }_{i t}+\beta_{12} \text { FRQ }_{i t}+\beta_{13} \text { Std_Sales }_{i t}+ \\
& \beta_{14} \text { Std_Cfo }_{i t}+\beta_{15} H H I_{i t}+\sum Y D+\sum I N D+\varepsilon_{i t}
\end{aligned}
$$

$L I S T_{i t}$ is an indicator variable that if firms are listed firms, it takes the value of 1 , and 0 otherwise. $\beta_{1}$ represents the differential investment efficiency for listed and unlisted firms. In the model (1), if the coefficient of LIST it $_{\text {shows a }}$ significant negative (-) value, it indicates that listed firms have higher investment efficiency than unlisted firms. On the other hand, if the coefficient of $L I S T_{i t}$ shows a significant positive (+) value, it indicates that listed firms have lower investment efficiency than unlisted firms.

We include numerous control variables associated with firms' investment efficiency. Since the higher firm size (SIZE) and profitability $(R O A)$, the higher investment efficiency is expected, the related variables are controlled (Chen et al., 2011). The ratio of cash holding ( $S L A C K$ ) is included to identify variables that affect either investment or financing. We also include variables on financial reporting quality (FRQ1, FRQ2, FRQ3) to control over-investment effects. Liu and Wysocki (2007) suggest that a combination of cash flow and sales volatilities subsumes the relation between accruals quality and proxies for the cost of capital. Thus, we control for the ratio of operating cash flow (Cfo_Sales) and sales volatility (Std_Sales). Additionally, we control for audit by a Big 4 audit firm (BIG4), the ratio of tangible assets $(T A N G)$, length of the operating cycle (OPCYCLE), whether a firm reports a loss or not (LOSS), operating cash flow volatility $\left(S t d \_C f o\right)$, and competitive intensity $(H H I)$. Finally, we include industry and year fixed effect.

\subsubsection{Effect of Big 4 Auditors on Investment Efficiency}

Because prior research finds that firms employing a Big 4 audit firm have a greater quality of financial reporting, we adapt the model (2) to catch the effect of Big 4 audit firms on investment efficiency as follows:

$\mathrm{s}$

$$
\begin{aligned}
& \operatorname{InvEff}_{i t}=\beta_{0}+\beta_{1} L_{I S T}+\beta_{2} B_{i G} 4_{i t}+\beta_{3} L I S T * B I G 4_{i t}+\beta_{4} \operatorname{SIZE}_{i t}+\alpha_{5} \text { TANG }_{i t}+\beta_{6} \text { SLACK }_{i t}+ \\
& \beta_{7} \text { OPCYCLE }_{i t}+\beta_{8} \text { LOSS }_{i t}+\beta_{9} R O A_{i t}+\beta_{10} \text { Cfo }_{-} \text {Sales }_{i t}+\beta_{11} F R Q 1_{i t}+\beta_{12} F R Q 2_{i t}+\beta_{13} F R Q 3_{i t}+ \\
& \beta_{14} \text { Std_Sales } i t+\beta_{15} \text { Std_Cfo }_{i t}+\beta_{16} H H I_{i t}+\sum Y D+\sum I N D+\varepsilon_{i t}
\end{aligned}
$$

In the model (2), the interest variable is $L I S T * B I G 4_{i t}$, which is the interaction variable between $L I S T_{i t}$ (an indicator variable indicating listing status) and $B I G 4_{i t}$ (an indicator variable indicating whether firms employing a Big 4 audit firm or not). The coefficient of $L I S T * B I G 4_{i t}$ indicates the difference in investment efficiency between listed firms employing a Big 4 audit firm and those that are not. If the coefficient value shows a significant negative (-) value, it means that the listed firms employing a Big 4 audit firm have a greater investment efficiency than those that do not. In other words, Big 4 audit firms provide high quality audit services, which can be seen as improving the investment efficiency of the firm. The control variables use the same variables as the model (1).

\subsection{Measurement of Variable}

\subsubsection{Investment Efficiency}

Based on a study conducted by Chen et al. (2011), we use investment forecasting model as a growth opportunity function. Thus, investment efficiency is measured by the residuals of investment forecasting model and both under- 
investment and over-investment are considered inefficient. When there are more than 10 samples in each industry according to the middle classification of the Korean standard industry classification, the following model (3) is regressed by year and industry to estimate the coefficients, and then investment efficiency is measured by the residuals. The forecasting model is:

$$
\text { Invest }_{i t}=\alpha_{0}+\alpha_{1} N E G_{i t-1}+\alpha_{2} \text { SalesGrowth }_{i t-1}+\alpha_{3} N E G_{i t-1} * \text { SalesGrowt }_{i t-1}+\varepsilon_{i t}
$$

Following Chen et al. (2011), we explain Invest $_{i t}$ as the total of new investment in equipment, machine, vehicle, buildings, lands, and R\&D expenditures, less the disposal of fixed assets, and scaled by lagged total assets for firm $\mathrm{i}$ in year t. Sales Growth ${ }_{i t-l}$ is the annual sales growth rate for firm i in year t-1. $N E G_{i t-l}$ takes the value of 1 for negative sales growth, and 0 otherwise. We classify inefficient investment as over-investment (if the residuals are greater than zero) and under-investment (if the residuals are less than zero). ${ }^{1}$ For ease of interpretation, the under-investment variable is multiplied by -1 . Thus, it is interpreted that the lower the value, the higher the investment efficiency regardless of the over-investment and under-investment.

\subsubsection{Financial Reporting Quality (FRQ)}

We employ three measures that have been used in prior research. The first measure is performance-adjusted discretionary accruals as developed by Kothari, Leone \& Wasley (2005). We estimate the following model by each industry that has at least 10 observations:

$$
\text { TAccr }_{i t}=\alpha_{0}+\alpha_{1}\left(1 / \text { Assets }_{i t-1}\right)+\alpha_{2} \Delta \operatorname{Rev}_{i t}+\alpha_{3} P P E_{i t}+\alpha_{4} R O A_{i t}+\varepsilon_{i t}
$$

where $T_{A c c r} r_{i t}$ is total accruals, measured as the change in non-cash current assets minus the change in current noninterest-bearing liabilities, minus depreciation and amortization expense for firm i at year $\mathrm{t}$, scaled by lagged total assets $\left(\right.$ Assets $\left._{\mathrm{it}-1}\right) ; \Delta \operatorname{Rev}_{i t}$ is the annual change in revenue scaled by lagged total assets; $P P E_{i t}$ is property, plant, and equipment for firm $\mathrm{i}$ at year $\mathrm{t}$, scaled by lagged total assets; $R O A_{i \mathrm{t}}$ is return on assets for firm $\mathrm{i}$ at year $\mathrm{t}$. The residuals from the regression model are discretionary accruals. We multiply the absolute values of discretionary accruals by -1 . Thus, higher values of discretionary accruals represent higher FRQ.

The second measure is based on the cross-sectional Dechow and Dichev (2002) model, as modified Francis et al. (2004). We estimate the following model by each industry that has at least 10 observations:

$$
\text { TACCr }_{i t}=\alpha_{0}+\alpha_{1} O C F_{i t-1}+\alpha_{2} O C F_{i t}+\alpha_{3} O C F_{i t+1}+\alpha_{4} \Delta R e v_{i t}+\alpha_{5} P P E_{i t}+\varepsilon_{i t}
$$

where $T_{A c c r}$ it is total current accruals, measured as the change in non-cash current assets minus the change in current non-interest-bearing liabilities, scaled by lagged total assets; $O C F$ is cash flow from operations; $\triangle R e v_{i t}$ is the annual change in revenue scaled by lagged total assets; $P P E_{i t}$ is property, plant, and equipment, scaled by lagged total assets. The residuals from the regression model are discretionary accruals. We multiply the absolute values of discretionary accruals by -1 . Thus, higher values of discretionary accruals represent higher FRQ.

Our third measure is the discretionary revenues as presented in McNichols and Stubben (2008). Specifically, we use the following regression:

$$
\Delta A R_{i t}=\alpha_{0}+\alpha_{1} \Delta R e v_{i t}+\varepsilon_{i t}
$$

where $\Delta A R_{i t}$ represents the annual change in accounts receivable and $\Delta \operatorname{Rev}_{i t}$ is the annual change in revenues, each scaled by lagged total assets. The residuals from the regression model are discretionary revenues. We multiply the absolute values of discretionary revenues by -1 . Thus, higher values of discretionary revenues represent higher FRQ.

\footnotetext{
${ }^{1}$ A residual greater than 0 means that there is more investment than the investment opportunity level, and a residual less than 0 means that there is less than the investment opportunity level. 


\subsection{Sample}

The total sample used in this study is the data of listed and unlisted firms in the Korea Stock Exchange (KSE) from 2002 to $2014 .^{2}$ We collect financial data from TS-2000 database for analysis. Financial institutions are excluded from the sample because their operating characteristics and financial statement accounts are different from non-financial firms. For comparability, we include only firms with fiscal year ends in December and total liabilities do not exceed total assets. We also excluded firms that are unable to collect the financial data required for our study. Finally, in order to remove the effect of extreme observations, all variables are winsorized at the upper/lower $1 \%$ level. The final sample used in our empirical analysis is 75,478 firm-year observations. In the yearly distribution, listed firms are 13,717 firm-year observations and unlisted firms are 61,761 firm-year observations from 2002 to 2014 (untabulated). The observations of unlisted firms are relatively large.

\section{EMPRICAL RESULTS}

\subsection{Descriptive Statistics and Correlations}

Table 1 provides descriptive statistics of the variables. Panel A shows descriptive statistics of the full samples. The mean of LIST is 0.182 and listed firms account for 18.2 percent of the full samples. The mean (median) of investment efficiency (InvEff) is $0.063(0.036)$. The mean of Big 4 audit firms (BIG4) is 0.287 and Big 4 audit firms account for 28.7 percent of the full samples. The mean (median) of firm size (SIZE) is 17.501 (17.194), the mean (median) of the ratio of tangible assets $(T A N G)$ is $0.342(0.317)$, the mean (median) of cash holding ratio (SLACK) is $0.062(0.032)$, and the mean (median) of operating cycle (OPCYCLE) is 4.603 (4.674). The mean (median) of return on assets (ROA) is 0.033 (0.031), the mean (median) of the ratio of operating cash flow (Cfo_Sales) is 0.047 (0.048), the mean (median) of sales volatility (Std_Sales) is 0.204 (0.134), and the mean (median) of operating cash flow volatility (Std_Cfo) is 0.084 (0.062). The mean of LOSS is 0.184 and loss firms account for 18.4 percent of the full samples.

Panel B shows descriptive statistics of the listed firm samples. The mean (median) of investment efficiency (InvEff) is 0.058 (0.035). The mean of Big 4 audit firms (BIG4) is 0.519 and Big 4 audit firms account for 51.9 percent of the listed firm samples. The mean (median) of firm size (SIZE) is 18.781 (18.508). The mean of LOSS is 0.256 and loss firms account for 25.6 percent of the listed firm samples. Panel $\mathrm{C}$ shows descriptive statistics of the unlisted firm samples. The mean (median) of investment efficiency (InvEff) is 0.064 (0.036). The mean of Big 4 audit firms (BIG4) is 0.236 and Big 4 audit firms account for 23.6 percent of the unlisted firm samples. The mean (median) of firm size (SIZE) is 17.217 (16.991). The mean of LOSS is 0.167 and loss firms account for 16.7 percent of the unlisted firm samples. Considering the mean and median of investment efficiency ( $I n v E f f)$, listed firms have lower values than unlisted firms. This indicates that listed firms invest more efficiently than unlisted firms.

\footnotetext{
${ }^{2}$ The Korea Stock Exchange consists of KOSPI (Korea Composite Stock Price Index) listed firms and KOSDAQ (Korea Securities Dealers Automated Quotation) listed firms. 
Table 1. Descriptive Statistics

\begin{tabular}{l|c|c|c|c|r|r|r|r}
\hline \multicolumn{1}{c}{$\begin{array}{c}\text { Panel A. Full Samples } \\
\text { Variable }\end{array}$} & $\begin{array}{c}\mathrm{N}=75,478) \\
\text { Mean }\end{array}$ & Std. & Min & Q1 & Median & Q3 & Max \\
\hline InvEff & 0.063 & 0.082 & 0.000 & 0.017 & 0.036 & 0.070 & 0.505 \\
\hline LIST & 0.182 & 0.386 & 0.000 & 0.000 & 0.000 & 0.000 & 1.000 \\
\hline BIG4 & 0.287 & 0.452 & 0.000 & 0.000 & 0.000 & 1.000 & 1.000 \\
\hline SIZE & 17.501 & 1.204 & 15.853 & 16.622 & 17.194 & 18.094 & 23.386 \\
\hline TANG & 0.342 & 0.243 & 0.000 & 0.142 & 0.317 & 0.504 & 0.956 \\
\hline SLACK & 0.062 & 0.081 & 0.000 & 0.009 & 0.032 & 0.083 & 0.434 \\
\hline OPCYCLE & 4.603 & 0.938 & 1.100 & 4.178 & 4.674 & 5.122 & 7.601 \\
\hline LOSS & 0.184 & 0.387 & 0.000 & 0.000 & 0.000 & 0.000 & 1.000 \\
\hline ROA & 0.033 & 0.085 & -0.568 & 0.006 & 0.031 & 0.071 & 0.287 \\
\hline Cfo_Sales & 0.047 & 0.203 & -1.211 & -0.006 & 0.048 & 0.116 & 0.723 \\
\hline FRQ1 & -0.077 & 0.080 & -0.451 & -0.101 & -0.052 & -0.023 & -0.001 \\
\hline FRQ2 & -0.066 & 0.069 & -0.386 & -0.087 & -0.044 & -0.019 & -0.001 \\
\hline FRQ3 & -0.213 & 0.251 & -1.358 & -0.271 & -0.126 & -0.051 & -0.001 \\
\hline Std_Sales & 0.204 & 0.222 & 0.005 & 0.065 & 0.134 & 0.257 & 1.353 \\
\hline Std_Cfo & 0.084 & 0.078 & 0.004 & 0.034 & 0.062 & 0.107 & 0.478 \\
\hline HHI & 0.081 & 0.078 & 0.006 & 0.029 & 0.047 & 0.113 & 0.815 \\
\hline
\end{tabular}

Panel B. Listed Firm Samples (N=13,717)

\begin{tabular}{|c|c|c|c|c|c|c|c|}
\hline Variable & Mean & Std. & Min & Q1 & Median & Q3 & Max \\
\hline InvEff & 0.058 & 0.071 & 0.000 & 0.016 & 0.035 & 0.068 & 0.433 \\
\hline$B I G 4$ & 0.519 & 0.500 & 0.000 & 0.000 & 1.000 & 1.000 & 1.000 \\
\hline SIZE & 18.781 & 1.388 & 16.373 & 17.841 & 18.508 & 19.449 & 23.386 \\
\hline$T A N G$ & 0.295 & 0.184 & 0.003 & 0.155 & 0.279 & 0.417 & 0.782 \\
\hline$S L A C K$ & 0.066 & 0.071 & 0.000 & 0.016 & 0.044 & 0.091 & 0.352 \\
\hline OPCYCLE & 4.790 & 0.653 & 2.656 & 4.436 & 4.813 & 5.199 & 6.335 \\
\hline LOSS & 0.256 & 0.436 & 0.000 & 0.000 & 0.000 & 1.000 & 1.000 \\
\hline$R O A$ & 0.010 & 0.115 & -0.568 & -0.003 & 0.030 & 0.066 & 0.211 \\
\hline Cfo_Sales & 0.042 & 0.152 & -0.723 & -0.006 & 0.051 & 0.112 & 0.425 \\
\hline$F R \bar{Q} 1$ & -0.064 & 0.063 & -0.331 & -0.086 & -0.045 & -0.020 & -0.001 \\
\hline$F R Q^{2}$ & -0.069 & 0.074 & -0.386 & -0.091 & -0.044 & -0.019 & -0.001 \\
\hline$F R Q 3$ & -0.157 & 0.182 & -1.009 & -0.198 & -0.097 & -0.042 & -0.001 \\
\hline Std_Sales & 0.142 & 0.138 & 0.007 & 0.053 & 0.100 & 0.181 & 0.791 \\
\hline Std_Cfo & 0.063 & 0.050 & 0.004 & 0.028 & 0.049 & 0.083 & 0.283 \\
\hline$H \overline{H I}$ & 0.097 & 0.090 & 0.006 & 0.032 & 0.050 & 0.131 & 0.815 \\
\hline
\end{tabular}

Panel C. Unlisted Firm Samples ( $\mathrm{N}=61,761)$

\begin{tabular}{|l|c|c|c|c|r|r|r|r}
\multicolumn{1}{c}{ Variable } & Mean & Std. & Min & Q1 & Median & Q3 & Max \\
\hline InvEff & 0.064 & 0.084 & 0.000 & 0.017 & 0.036 & 0.071 & 0.505 \\
\hline BIG4 & 0.236 & 0.425 & 0.000 & 0.000 & 0.000 & 0.000 & 1.000 \\
\hline SIZE & 17.217 & 0.948 & 15.853 & 16.535 & 16.991 & 17.675 & 20.642 \\
\hline TANG & 0.352 & 0.253 & 0.000 & 0.138 & 0.329 & 0.527 & 0.956 \\
\hline SLACK & 0.061 & 0.083 & 0.000 & 0.008 & 0.029 & 0.080 & 0.434 \\
\hline OPCYCLE & 4.561 & 0.985 & 1.100 & 4.111 & 4.633 & 5.101 & 7.601 \\
\hline LOSS & 0.167 & 0.373 & 0.000 & 0.000 & 0.000 & 0.000 & 1.000 \\
\hline ROA & 0.039 & 0.076 & -0.232 & 0.007 & 0.031 & 0.072 & 0.287 \\
\hline Cfo_Sales & 0.048 & 0.212 & -1.211 & -0.005 & 0.047 & 0.117 & 0.723 \\
\hline FRQ1 & -0.080 & 0.083 & -0.451 & -0.104 & -0.054 & -0.023 & -0.001 \\
\hline FRQ2 & -0.065 & 0.068 & -0.355 & -0.087 & -0.044 & -0.019 & -0.001 \\
\hline FRQ3 & -0.225 & 0.263 & -1.358 & -0.288 & -0.134 & -0.053 & -0.002 \\
\hline Std_Sales & 0.218 & 0.234 & 0.005 & 0.070 & 0.144 & 0.276 & 1.353 \\
\hline Std_Cfo & 0.089 & 0.082 & 0.005 & 0.035 & 0.066 & 0.113 & 0.478 \\
\hline HHI & 0.077 & 0.075 & 0.006 & 0.028 & 0.046 & 0.111 & 0.815 \\
\hline Not Tis & & & &
\end{tabular}

Note: This table provides descriptive statistics for the variables used in the analysis. Variable definitions are described in Appendix. 
Table 2 provides the test of differences in variables. Listed firms have a lower the mean and median of investment efficiency (InvEff) than unlisted firms. This indicates that listed firms invest more efficiently than unlisted firms. Listed firms have a greater mean of Big 4 audit firms (BIG4) than unlisted firms. This suggests that listed firms employ more Big 4 auditors than unlisted firms. In addition, listed firms have a greater mean of SIZE, SLACK, OPCYCLE, LOSS, FRQ1, FRQ2, and HHI than unlisted firms, while unlisted firms have a greater mean of TANG, ROA, Cfo_Sales, FRQ2,Std_Sales, and Std_Cfo than listed firms.

Table 2. Test of Differences in Variables

\begin{tabular}{|c|c|c|c|}
\hline Variable & $\begin{array}{c}\text { Listed Firm } \\
(\mathrm{N}=13,717)\end{array}$ & $\begin{array}{c}\text { Unlisted Firm } \\
(\mathrm{N}=61,761)\end{array}$ & Test of Differences \\
\hline$I n v E f f$ & 0.058 & 0.064 & $-0.006^{* * *}$ \\
\hline$B I G 4$ & 0.519 & 0.236 & $0.283^{* * *}$ \\
\hline SIZE & 18.781 & 17.217 & $1.564^{* * *}$ \\
\hline$T A N G$ & 0.295 & 0.352 & $-0.057^{* * *}$ \\
\hline$S L A C K$ & 0.066 & 0.061 & $0.005^{* * *}$ \\
\hline OPCYCLE & 4.790 & 4.561 & $0.229^{* * *}$ \\
\hline LOSS & 0.256 & 0.167 & $0.089^{* * *}$ \\
\hline$R O A$ & 0.010 & 0.039 & $-0.029^{* * *}$ \\
\hline Cfo_Sales & 0.042 & 0.048 & $-0.006^{* * *}$ \\
\hline$F R \bar{Q} 1$ & -0.064 & -0.080 & $0.016^{* * *}$ \\
\hline$F R Q 2$ & -0.069 & -0.065 & $-0.003^{* * *}$ \\
\hline$F R Q 3$ & -0.157 & -0.225 & $0.067^{* * *}$ \\
\hline Std Sales & 0.142 & 0.218 & $-0.076^{* * *}$ \\
\hline Std_Cfo & 0.063 & 0.089 & $-0.026^{* * *}$ \\
\hline$H H I$ & 0.097 & 0.077 & $0.019^{* * *}$ \\
\hline
\end{tabular}

Note: This table provides test of differences in variables used in the analysis. $* * *$ represent significance at the 0.01 level. Variable definitions are described in Appendix.

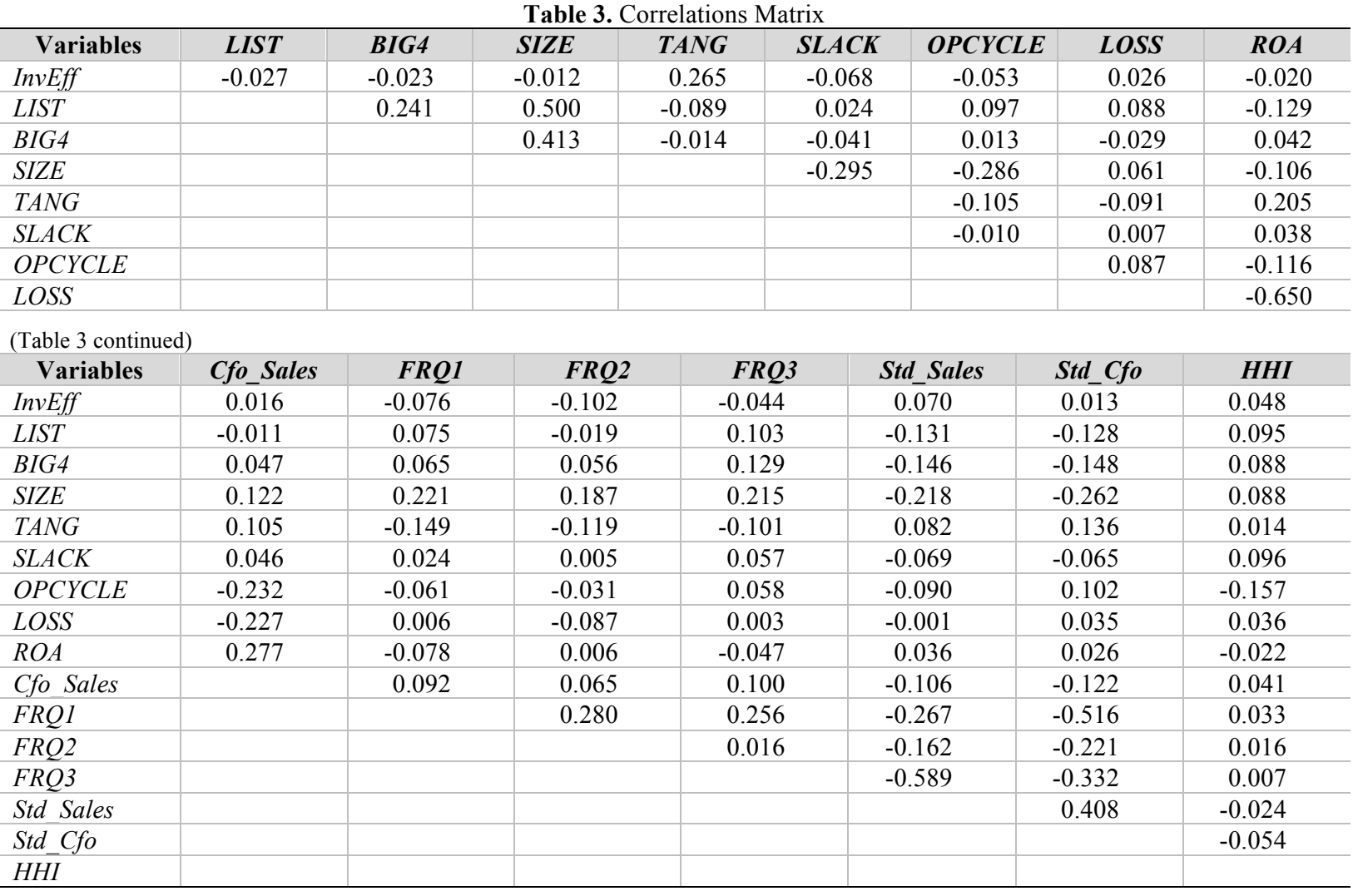


Table 3 provides the Pearson correlations. The dependent variable, investment efficiency (InvEff) and listing statues (LIST) shows a significant negative (-) correlation. This indicates that listed firms are more efficient than unlisted firms. Investment efficiency (InvEff) show significant negative (-) correlations with Big4, SIZE, SLACK, OPCYCLE, $R O A, F R Q 1, F R Q 2$, and FRQ3 and show significant positive (+) correlations with TANG, LOSS,CCfo_Sales, Std_Sales, Std_Cfo, and HHI. The results show that firms with high quality of financial reporting are making efficient investments and that inefficient investments are made due to the effects of competition in industries with high competition intensity. It seems that there is a tendency to deviate from expectations when operating cash flow and sales volatility are large and losses occur. As a result of examining the VIF to determine the existence of multi-collinearity between variables, there is no multi-collinearity problem in all variables. Since the above results do not control the effect of other variables on investment efficiency, we conduct multivariate regression analysis including several control variables.

\subsection{Multivariate Results}

\subsubsection{Difference in Investment Efficiency Between Listed and Unlisted Firms}

Table 4 provides the regression results of testing $\mathrm{H} 1$ by showing the difference in investment efficiency between listed and unlisted firms. In the full sample, the coefficient of $L I S T$ is significantly negative $\left(\beta_{1}=-0.002, \mathrm{t}=-1.94\right)$, suggesting that investment efficiency of listed firms is greater than investment efficiency of unlisted firms. Since listed firms have a better quality of financial reporting than unlisted firms, information asymmetry, costs of financing, and reverse selection costs are reduced. For this reason, listed firms are interpreted as investing more efficiently.

In the over-investment, the coefficient of LIST is significantly negative $\left(\beta_{1}=-0.007, t=-3.27\right)$, suggesting that investment efficiency of listed firms is greater than investment efficiency of unlisted firms. The results mean that listed firms have superior financial reporting quality than unlisted firms, which suppress over-investment caused by opportunistic behavior of managers. On the contrary, in the under-investment, the coefficient of LIST is significantly positive $\left(\beta_{1}=0.003, t=4.36\right)$, suggesting that investment efficiency of unlisted firms is greater than investment efficiency of listed firms. This finding implies that listed firms are more interested in over-investment than underinvestment.

In sum, the results in Table 4 show that listed firms are more efficient in over-investment, while unlisted firms are more efficient in under-investment. These results mean that there is a difference in investment efficiency between listed and unlisted firms according to over-investment and under-investment.

The results of control variables are generally consistent with prior study (Chen et al., 2011). Audit of Big 4 audit firms (BIG4), firm size (SIZE), and financial reporting quality (FRQ1, FRQ2, FRQ3) show significant negative (-) relationships with investment efficiency (InvEff). This finding indicates that the firms employing a Big 4 audit firm are showing relatively high investment efficiency, and large-scale firms have high investment efficiency due to the monitoring effect of stakeholders. In addition, financial reporting quality mitigates over-investment and underinvestment (Chen et al., 2011).

Tangible assets $(T A N G)$, length of the operating cycle (OPCYCLE), return on assets (ROA), operating cash flow to sales (Cfo_Sales), and volatility of sales (Std_Sales) show significant positive $(+)$ relationships with investment efficiency $(I n v E f f)$. The results show that there is a tendency to make an investment that deviates from proper investment when operating cash flow volatility and sales volatility are high and losses occur. 
Table 4. Analysis of Difference in Investment Efficiency between Listed and Unlisted Firms

\begin{tabular}{|c|c|c|c|c|c|c|}
\hline \multirow{2}{*}{ Variable } & \multicolumn{2}{|c|}{ Full Sample $(\mathrm{N}=\mathbf{7 5 , 4 7 8 )}$} & \multicolumn{2}{|c|}{ Over-investment $(\mathrm{N}=\mathbf{2 6 , 0 4 8 )}$} & \multicolumn{2}{|c|}{ Under-investment $(\mathrm{N}=49,430)$} \\
\hline & Coefficient & t-value & Coefficient & t-value & Coefficient & t-value \\
\hline Intercept & $-0.052^{* * *}$ & -4.28 & $-0.163^{* * *}$ & -6.25 & $0.085^{* * *}$ & 9.63 \\
\hline LIST & $-0.002^{*}$ & -1.94 & $-0.007^{* * *}$ & -3.27 & $0.003^{* * *}$ & 4.36 \\
\hline$B I G 4$ & $-0.002^{* *}$ & -2.32 & -0.002 & -1.02 & $0.001^{* *}$ & 2.35 \\
\hline$S I Z E$ & $0.002^{* * *}$ & -7.08 & $-0.003^{* * *}$ & -4.24 & $-0.002^{* * *}$ & -9.13 \\
\hline$T A N G$ & $0.120^{* * *}$ & 81.39 & $0.251^{* * *}$ & 69.37 & $0.023^{* * *}$ & 22.79 \\
\hline$S L A C K$ & -0.003 & -0.76 & 0.002 & 0.30 & 0.001 & 0.11 \\
\hline OPCYCLE & $0.004^{* * *}$ & 9.70 & $0.010^{* * *}$ & 10.38 & $-0.001^{* * *}$ & -4.91 \\
\hline LOSS & -0.001 & -0.44 & $-0.007^{* * *}$ & -2.96 & $0.004^{* * *}$ & 7.39 \\
\hline$R O A$ & $0.012^{* *}$ & 2.38 & 0.014 & 1.29 & 0.001 & 0.19 \\
\hline Cfo_Sales & $0.003^{*}$ & 1.93 & $0.015^{* * *}$ & 4.13 & $-0.011^{* * *}$ & -11.06 \\
\hline$F R \bar{Q} 1$ & $-0.093^{* * *}$ & -22.46 & $-0.151^{* * *}$ & -16.25 & $-0.033^{* * *}$ & -11.76 \\
\hline$F R Q 2$ & $-0.141^{* * *}$ & -32.74 & $-0.221^{* * *}$ & -23.23 & $-0.044^{* * *}$ & -14.75 \\
\hline$F R Q 3$ & $-0.006^{* * *}$ & -4.09 & $-0.007^{* * *}$ & -5.43 & $0.003^{* *}$ & 2.45 \\
\hline Std_Sales & $0.038^{* * *}$ & 23.24 & $0.080^{* * *}$ & 21.75 & $0.003^{* * *}$ & 2.81 \\
\hline$S t d \_C f o$ & $0.012^{* * *}$ & 2.72 & $0.026^{* *}$ & 2.48 & 0.002 & 0.73 \\
\hline$H \overline{H I}$ & -0.013 & -1.22 & -0.007 & -0.33 & $-0.020^{* *}$ & -2.54 \\
\hline $\begin{array}{l}\text { Year and Industry } \\
\text { Dummy }\end{array}$ & \multicolumn{2}{|c|}{ Included } & \multicolumn{2}{|c|}{ Included } & \multicolumn{2}{|c|}{ Included } \\
\hline Adj. $R^{2}$ & \multicolumn{2}{|c|}{$14.52 \%$} & \multicolumn{2}{|c|}{$24.13 \%$} & \multicolumn{2}{|c|}{$11.34 \%$} \\
\hline
\end{tabular}

Note: This table reports the results of difference in investment efficiency between listed and unlisted firms. ${ }^{* * *},{ }^{* *}, *$ represent significance at the $0.01,0.05$, and 0.1 level, respectively. Variable definitions are described in Appendix.

\subsubsection{Effect of Big 4 Audit Firms on Investment Efficiency}

Table 5 provides the regression results of testing $\mathrm{H} 2$ that listed firms employing a Big 4 audit firm will have a greater investment efficiency than those that do not. In the full sample, the coefficient of LIST*BIG4 is negative and significant $\left(\beta_{1}=-0.006, \mathrm{t}=-3.05\right)$ at 0.01 level. This finding indicates that Big 4 audit firms have more efficient resources and expertise in performing an audit, which increases the credibility of accounting information and improves investment efficiency.

In the over-investment, the coefficient of $L I S T^{*} B I G 4$ is significantly negative $\left(\beta_{1}=-0.010, \mathrm{t}=-2.84\right)$ at 0.01 level. On the contrary, in the under-investment, the coefficient of $L I S T^{*} B I G 4$ is not significant. The results suggest that just as firms' litigation risk is greater in upward earnings management than downward earnings management, the audit effect of Big 4 audit firms in the over-investment sample greatly contributed to the restraint of over-investment compared to the under-investment sample. 
Table 5. Effect of Big 4 Audit Firms on Investment Efficiency

\begin{tabular}{|c|c|c|c|c|c|c|}
\hline \multirow{2}{*}{ Variable } & \multicolumn{2}{|c|}{ Full Sample $(\mathrm{N}=75,478)$} & \multicolumn{2}{|c|}{ Over-investment $(\mathrm{N}=\mathbf{2 6 , 0 4 8 )}$} & \multicolumn{2}{|c|}{ Under-investment $(\mathrm{N}=49,430)$} \\
\hline & Coefficient & t-value & Coefficient & t-value & Coefficient & t-value \\
\hline Intercept & $-0.053^{* * *}$ & -4.32 & $-0.163^{* * *}$ & -6.25 & $0.085^{* * *}$ & 9.63 \\
\hline LIST & 0.001 & 0.30 & -0.002 & -0.91 & $0.003^{* * *}$ & 3.32 \\
\hline BIG4 & -0.001 & -0.67 & 0.001 & 0.46 & $0.001^{* *}$ & 1.99 \\
\hline $\mathrm{LIST}^{*} \mathrm{BIG} 4$ & $-0.006^{* * *}$ & -3.05 & $-0.010^{* * *}$ & -2.84 & 0.001 & 0.24 \\
\hline SIZE & $-0.002^{* * *}$ & -7.16 & $-0.003^{* * *}$ & -4.31 & $-0.002^{* * *}$ & -9.13 \\
\hline TANG & $0.120^{* * *}$ & 81.45 & $0.252^{* * *}$ & 69.44 & $0.023^{* * *}$ & 22.76 \\
\hline SLACK & -0.003 & -0.88 & 0.002 & 0.23 & 0.001 & 0.12 \\
\hline OPCYCLE & $0.004^{* * *}$ & 9.64 & $0.010^{* * *}$ & 10.83 & $-0.001^{* * *}$ & -4.91 \\
\hline LOSS & -0.001 & -0.50 & $-0.007^{* * *}$ & -3.02 & $0.005^{* * *}$ & 7.39 \\
\hline ROA & $0.011^{* *}$ & 2.41 & 0.015 & 1.34 & 0.001 & 0.18 \\
\hline Cfo Sales & $0.003^{*}$ & 1.93 & $0.015^{* * *}$ & 4.14 & $-0.011^{* * *}$ & -11.06 \\
\hline FRQ̄1 & $-0.094^{* * *}$ & -22.44 & $-0.151^{* * *}$ & -16.23 & $-0.034^{* * *}$ & -11.76 \\
\hline FRQ2 & $-0.141^{* * *}$ & -32.71 & $-0.221^{* * *}$ & -23.17 & $-0.044^{* * *}$ & -14.75 \\
\hline FRQ3 & -0.006 & $-4.10^{* * *}$ & $-0.017^{* * *}$ & -5.42 & $0.002^{* *}$ & 2.45 \\
\hline Std_Sales & $0.038^{* * *}$ & 23.28 & $0.081^{* * *}$ & 21.79 & $0.003^{* * *}$ & 2.81 \\
\hline Std_Cfo & $0.012^{* * *}$ & 2.72 & $0.027^{* *}$ & 2.49 & 0.002 & 0.73 \\
\hline HHI & -0.013 & -1.20 & -0.007 & -0.32 & $-0.021^{* *}$ & -2.54 \\
\hline $\begin{array}{l}\text { Year and Industry } \\
\text { Dummy }\end{array}$ & \multicolumn{2}{|c|}{ Included } & \multicolumn{2}{|c|}{ Included } & \multicolumn{2}{|c|}{ Included } \\
\hline Adj. R2 & \multicolumn{2}{|c|}{$14.62 \%$} & \multicolumn{2}{|c|}{$24.23 \%$} & \multicolumn{2}{|c|}{$12.34 \%$} \\
\hline
\end{tabular}

Note: This table reports the results of the effect of Big 4 audit firms on investment efficiency. $* * * * *, *$ represent significance at the $0.01,0.05$, and 0.1 level, respectively. Variable definitions are described in Appendix.

\subsection{Additional Analysis}

\subsubsection{Propensity-Score Matching}

The primary difference between listed and unlisted firms is size, and size can account for investment efficiency. Thus, we rely on propensity score matched (PSM) samples. For the PSM approach, we use the log of total assets, return on equity, financial leverage, and asset growth. In the first step, a logit model is estimated to predict the probability that the firm is unlisted, conditional on the four matching characteristics. We then match, without replacement, firms that are listed and unlisted, based on closeness to the predicted value from the first step. The PSM approach generates samples in which listed and unlisted firms are more similar, which helps mitigate concerns that omitted correlated variables are driving our results.

Table 6 provides the regression results of testing H1 using Propensity Score Matching (PSM). In the full sample, the coefficient of LIST is not significantly negative $\left(\beta_{1}=-0.001, \mathrm{t}=-0.62\right)$. In the over-investment, the coefficient of LIST is significantly negative $\left(\beta_{1}=-0.008, \mathrm{t}=-3.63\right)$, suggesting that investment efficiency of listed firms is greater than investment efficiency of unlisted firms. On the contrary, in the under-investment, the coefficient of LIST is significantly positive $\left(\beta_{1}=0.003, \mathrm{t}=4.36\right)$, suggesting that investment efficiency of unlisted firms is greater than investment efficiency of listed firms. The regression results of testing H1 using Propensity Score Matching (PSM) are consistent with the results of Table 4. In sum, the results in Table 6 show that listed firms are more efficient in overinvestment, while unlisted firms are more efficient in under-investment. These results mean that there is a difference in investment efficiency between listed and unlisted firms according to over-investment and under-investment. 
Table 6. Analysis of H1 using Propensity Score Matching (PSM)

\begin{tabular}{|c|c|c|c|c|c|c|}
\hline \multirow{2}{*}{ Variable } & \multicolumn{2}{|c|}{ Full Sample $(\mathrm{N}=27,434)$} & \multicolumn{2}{|c|}{ Over-investment $(\mathrm{N}=9,972)$} & \multicolumn{2}{|c|}{ Under-investment $(\mathrm{N}=17,462)$} \\
\hline & Coefficient & t-value & Coefficient & t-value & Coefficient & t-value \\
\hline Intercept & -0.003 & -0.15 & -0.032 & -0.81 & $0.060^{* * *}$ & 3.49 \\
\hline LIST & -0.001 & -0.62 & $-0.008^{* * *}$ & -3.63 & $0.002^{* * *}$ & 3.28 \\
\hline BIG4 & -0.001 & -1.29 & -0.002 & -0.92 & $0.002^{* * *}$ & 3.20 \\
\hline SIZE & $-0.001^{* * *}$ & -2.73 & $-0.005^{* * *}$ & -4.88 & $-0.001^{* * *}$ & -2.87 \\
\hline TANG & $0.126^{* * *}$ & 50.82 & $0.260^{* * *}$ & 46.64 & $0.015^{* * *}$ & 8.50 \\
\hline SLACK & $-0.019^{* * *}$ & -2.99 & $-0.040^{* * *}$ & -.74 & 0.004 & 0.91 \\
\hline OPCYCLE & $0.004^{* * *}$ & 6.65 & $0.011^{* * *}$ & 7.79 & $-0.002^{* * *}$ & -3.95 \\
\hline LOSS & 0.001 & 0.69 & -0.003 & -0.86 & $0.003^{* * *}$ & 3.00 \\
\hline ROA & 0.002 & 0.24 & $0.045^{* * *}$ & 2.91 & $-0.049^{* * *}$ & -11.22 \\
\hline Cfo_Sales & 0.003 & 1.31 & 0.006 & 1.26 & $-0.005^{* * *}$ & -2.99 \\
\hline FRQ̄1 & $-0.114^{* * *}$ & -15.64 & $-0.191^{* * *}$ & -12.58 & $-0.029^{* * *}$ & -5.42 \\
\hline FRQ2 & $-0.143^{* * *}$ & -21.59 & $-0.218^{* * *}$ & -16.20 & $-0.030^{* * *}$ & -6.13 \\
\hline FRQ3 & $-0.015^{* * *}$ & -5.23 & $-0.023^{* * *}$ & -4.08 & $-0.009^{* * *}$ & -4.38 \\
\hline Std_Sales & $0.051^{* * *}$ & 15.26 & $0.103^{* * *}$ & 14.94 & 0.001 & 0.32 \\
\hline Std_Cfo & $-0.039^{* * *}$ & -4.36 & $-0.060^{* * *}$ & -3.15 & $-0.022^{* * *}$ & -3.50 \\
\hline $\mathrm{HHI}$ & 0.006 & 0.39 & 0.018 & 0.60 & 0.001 & 0.06 \\
\hline $\begin{array}{l}\text { Year and Industry } \\
\text { Dummy }\end{array}$ & \multicolumn{2}{|c|}{ Included } & \multicolumn{2}{|c|}{ Included } & \multicolumn{2}{|c|}{ Included } \\
\hline Adj. R2 & \multicolumn{2}{|c|}{$16.2 \%$} & \multicolumn{2}{|c|}{$28.7 \%$} & \multicolumn{2}{|c|}{$10.4 \%$} \\
\hline
\end{tabular}

Note: This table reports the results of testing H1 using Propensity Score Matching (PSM).***,**, * represent significance at the $0.01,0.05$, and 0.1 level, respectively. Variable definitions are described in Appendix

Table 7 provides the regression results of testing H2 using Propensity Score Matching (PSM). In the full sample and over-investment sample, the coefficient of $L I S T^{*} B I G 4$ is not significantly negative. On the contrary, in the underinvestment, the coefficient of $L I S T^{*} B I G 4$ is negative and significant $\left(\beta_{1}=-0.003, \mathrm{t}=-2.19\right)$ at 0.05 level. This finding indicates that Big 4 audit firms have more efficient resources and expertise in performing an audit, which increases the credibility of accounting information and improves investment efficiency. The regression results of testing $\mathrm{H} 2$ using Propensity Score Matching (PSM) are inconsistent with the results of Table 4. These results mean that there is a difference in investment efficiency between listed and unlisted firms according to over-investment and underinvestment. 
Table 7. Analysis of $\mathrm{H} 2$ using Propensity Score Matching (PSM)

\begin{tabular}{|c|c|c|c|c|c|c|}
\hline \multirow{2}{*}{ Variable } & \multicolumn{2}{|c|}{ Full Sample $(\mathrm{N}=27,434)$} & \multicolumn{2}{|c|}{ Over-investment $(\mathrm{N}=9,972)$} & \multicolumn{2}{|c|}{ Under-investment $(\mathrm{N}=17,462)$} \\
\hline & Coefficient & t-value & Coefficient & t-value & Coefficient & t-value \\
\hline Intercept & -0.003 & -0.16 & -0.032 & -0.80 & $0.060^{* * * *}$ & 3.46 \\
\hline LIST & -0.001 & -0.22 & $-0.008^{* * *}$ & -2.83 & $0.004^{* * *}$ & 3.91 \\
\hline BIG4 & -0.001 & -0.47 & -0.002 & -0.74 & $0.004^{* * *}$ & 3.84 \\
\hline LIST*BIG4 & -0.001 & -0.70 & -0.001 & -0.12 & $-0.003^{* *}$ & -2.19 \\
\hline SIZE & $-0.001^{* * *}$ & -2.70 & $-0.005^{* * *}$ & -4.88 & $-0.001^{* * *}$ & -2.78 \\
\hline TANG & $0.126^{* * *}$ & 50.82 & $0.260^{* * *}$ & 46.64 & $0.015^{* * *}$ & 8.53 \\
\hline SLACK & $-0.019^{* * *}$ & -3.00 & $-0.040^{* * *}$ & -2.74 & 0.004 & 0.86 \\
\hline OPCYCLE & $0.004^{* * *}$ & 6.62 & $0.011^{* * *}$ & 7.79 & $-0.002^{* * *}$ & -4.02 \\
\hline LOSS & 0.001 & 0.69 & -0.003 & -0.86 & $0.003^{* * *}$ & 3.02 \\
\hline ROA & 0.002 & 0.25 & $0.045^{* * *}$ & 2.90 & $-0.049^{* * *}$ & -11.20 \\
\hline Cfo_Sales & 0.003 & 1.30 & 0.006 & 1.26 & $-0.005^{* * *}$ & -3.02 \\
\hline FRQ1 & $-0.114^{* * *}$ & -15.62 & $-0.191^{* * *}$ & -12.58 & $-0.028^{* * *}$ & -5.39 \\
\hline FRQ2 & $-0.143^{* * *}$ & -21.59 & $-0.218^{* * *}$ & -16.20 & $-0.030^{* * *}$ & -6.17 \\
\hline FRQ3 & $-0.015^{* * *}$ & -5.22 & $-0.023^{* * *}$ & -4.08 & $-0.009^{* * *}$ & -4.38 \\
\hline Std Sales & $0.051^{* * *}$ & 15.26 & $0.103^{* * *}$ & 14.94 & 0.001 & 0.31 \\
\hline Std Cfo & $-0.038^{* * *}$ & -4.36 & $-0.060^{* * *}$ & -3.15 & $-0.021^{* * *}$ & -3.48 \\
\hline $\mathrm{HH} \overline{\mathrm{I}}$ & 0.006 & 0.40 & 0.018 & 0.60 & 0.001 & 0.08 \\
\hline $\begin{array}{l}\text { Year and Industry } \\
\text { Dummy }\end{array}$ & \multicolumn{2}{|c|}{ Included } & \multicolumn{2}{|c|}{ Included } & \multicolumn{2}{|c|}{ Included } \\
\hline Adj. R2 & \multicolumn{2}{|c|}{$16.2 \%$} & \multicolumn{2}{|c|}{$28.7 \%$} & \multicolumn{2}{|c|}{$10.4 \%$} \\
\hline
\end{tabular}

Note: This table reports the results of testing H2 using Propensity Score Matching (PSM). ${ }^{* * *},{ }^{* *},{ }^{*}$ represent significance at the $0.01,0.05$, and 0.1 level, respectively. Variable definitions are described in Appendix.

\subsubsection{Difference in Investment Efficiency between KOSPI, KOSDAQ Listed Firms and Unlisted Firms}

Even in the case of listed firms, there are several differences in the case of KOSPI (Korea Composite Stock Price Index) and KOSDAQ (Korea Securities Dealers Automated Quotation) listed firms. The KOSDAQ market operates almost similarly to the operating system of the US Nasdaq market. In the KOSPI market, existing traditional firms and large-scale firms are listed, and small and medium-sized firms such as venture firms with technology and growth potential are listed on the KOSDAQ market. Thus, differences in market characteristics between KOSPI and KOSDAQ listed firms are expected to affect the FRQ.

Table 8 provides the regression results of retesting $\mathrm{H} 1$ by classifying listed firms as KOSPI and KOSDAQ listed firms. In the full sample, the coefficient of KOSPI is significantly negative $\left(\beta_{1}=-0.008, \mathrm{t}=-6.01\right)$ at one percent level. In the over-investment, the coefficient of KOSPI is significantly negative $\left(\beta_{1}=-0.019, \mathrm{t}=-6.23\right)$ at one percent level. The results show that the KOSPI listed firms have higher investment efficiency than the unlisted firms. However, the coefficient of KOSDAQ is not significant in the full and over-investment sample. The difference in investment efficiency between listed and unlisted firms is due to the difference effect of the KOSPI listed firms among listed firms. In addition, in the under-investment, the coefficient of $K O S P I$ is significantly negative $\left(\beta_{1}=0.005, \mathrm{t}=5.45\right)$, suggesting that the investment efficiency of unlisted firms is a greater than that of KOSPI listed firms. 
Table 8. Analysis of Difference in Investment Efficiency between KOSPI, KOSDAQ Listed Firms and Unlisted Firms

\begin{tabular}{|c|c|c|c|c|c|c|}
\hline \multirow{2}{*}{ Variable } & \multicolumn{2}{|c|}{ Full Sample $(\mathrm{N}=\mathbf{7 5 , 4 7 8 )}$} & \multicolumn{2}{|c|}{ Over-investment $(\mathrm{N}=\mathbf{2 6 , 0 4 8 )}$} & \multicolumn{2}{|c|}{ Under-investment $(\mathrm{N}=49,430)$} \\
\hline & Coefficient & t-value & Coefficient & t-value & Coefficient & t-value \\
\hline Intercept & $-0.061^{* * *}$ & -4.94 & $-0.181^{* * *}$ & -6.87 & $0.088^{* * *}$ & 9.91 \\
\hline KOSPI & $-0.008^{* * *}$ & -6.01 & $-0.019^{* * *}$ & -6.23 & $0.005^{* * *}$ & 5.45 \\
\hline KOSDAQ & 0.002 & 1.64 & -0.001 & -0.44 & $0.001^{*}$ & 1.91 \\
\hline BIG4 & $-0.002^{* *}$ & -2.26 & 0.002 & 0.94 & $0.001^{* *}$ & 2.33 \\
\hline SIZE & $0.003^{* * *}$ & 8.57 & $0.004^{* * *}$ & 5.60 & $-0.002^{* * *}$ & -9.68 \\
\hline TANG & $0.121^{* * *}$ & 81.59 & $0.252^{* * *}$ & 69.56 & $0.022^{* * *}$ & 22.61 \\
\hline SLACK & -0.003 & -0.89 & 0.002 & 0.21 & 0.001 & 0.18 \\
\hline OPCYCLE & $0.004^{* * *}$ & 9.57 & $0.010^{* * *}$ & 10.75 & $-0.001^{* * *}$ & -4.88 \\
\hline LOSS & -0.001 & -0.47 & $-0.007^{* * *}$ & -3.08 & $0.005^{* * *}$ & 7.38 \\
\hline ROA & $0.011^{* *}$ & 2.49 & 0.015 & 1.35 & 0.001 & 0.11 \\
\hline Cfo_Sales & $0.003^{*}$ & 1.81 & $0.015^{* * *}$ & 4.01 & $-0.011^{* * *}$ & -11.01 \\
\hline FRQ1 & $-0.094^{* * *}$ & -22.31 & $-0.150^{* * *}$ & -16.13 & $-0.034^{* * *}$ & -11.83 \\
\hline FRQ2 & $-0.139^{* * *}$ & -32.46 & $-0.219^{* * *}$ & -22.94 & $-0.044^{* * *}$ & -14.84 \\
\hline FRQ3 & $-0.006^{* * *}$ & -4.08 & $-0.017^{* * *}$ & -5.48 & $0.002^{* *}$ & 2.43 \\
\hline Std_Sales & $0.038^{* * *}$ & 23.31 & $0.080^{* * *}$ & 21.77 & $0.003^{* * *}$ & 2.75 \\
\hline Std_Cfo & $-0.013^{* * *}$ & -2.68 & $-0.026^{* *}$ & -2.44 & -0.002 & -0.74 \\
\hline HHI & -0.014 & -1.25 & -0.008 & -0.36 & $-0.021^{* *}$ & -2.52 \\
\hline $\begin{array}{l}\text { Year and Industry } \\
\text { Dummy }\end{array}$ & \multicolumn{2}{|c|}{ Included } & \multicolumn{2}{|c|}{ Included } & \multicolumn{2}{|c|}{ Included } \\
\hline Adj. R2 & \multicolumn{2}{|c|}{$14.52 \%$} & \multicolumn{2}{|c|}{$24.21 \%$} & \multicolumn{2}{|c|}{$11.33 \%$} \\
\hline
\end{tabular}

Note: This table reports the results of difference in investment efficiency between KOSPI, KOSDAQ listed firms and unlisted firms. ***, **, * represent significance at the $0.01,0.05$, and 0.1 level, respectively. Variable definitions are described in Appendix.

\section{CONCLUSION}

We examine the difference in investment efficiency between listed and unlisted firms and the effect of auditing by Big 4 audit firms on the investment efficiency of firms. Generally, listed firms are large in size, have a high level of stakeholders' demands on the firm information, and show large ripple effects of managers' decision. Prior studies show that listed firms have a greater FRQ than unlisted firms. The higher financial reporting quality has been shown to reduce both the under-investments of firms that face financial constraints and the over-investments occurring in firms that have large amounts of cash and free cash flows (Biddle et al. 2009).

As a result of the study, in the analysis of full samples, the listed firms have significantly higher investment efficiency than the unlisted ones. In the over-investment samples, it is found that the listed firms have higher investment efficiency. On the contrary, in the under-investment samples, it is found that the unlisted firms have higher investment efficiency. In addition, it is found that listed firms employing a Big 4 audit firm have a greater investment efficiency. In further analysis, listed firms are classified into the KOSPI and KOSDAQ listed firms. As a result of comparing with the unlisted firms, it is found that the KOSPI listed firms have higher investment efficiency than the KOSDAQ listed firms and unlisted firms.

This study makes the following contributions. First, this study is expected to help in understanding the characteristics of financial reporting provided by listed and unlisted firms by presenting empirical results on investment efficiency as over-investment and under-investment. Second, our results show that the audit by Big 4 audit firms produces high quality accounting information and affects the improvement of investment efficiency. Finally, it is expected that it will provide useful information on investment efficiency by expanding the scope of research and making the measurement of variables more precise. Limitations of our study include the fact that there is still a problem of omitted variables in the regression model of investment efficiency. 


\section{AUTHOR BIOGRAPHIES}

Sambock Park, Assistant Professor, Dept. of Accounting and Tax, Hanyang University, 55 Hanyang Daehak-ro, Sangnokgu, Ansan-si, Gyeonggi-do, South Korea. E-mail: psp96@hanyang.ac.kr (First Author).

Imhyeon Kim, Ph.D. Candidate, Graduate School of Business, Hanyang University, 222 Wangsimni-ro, Seongdong-gu, Seoul 04763, South Korea. E-mail: hsbkih@hanyang.ac.kr (Corresponding Author).

Wooyoung Kim, Associate Professor, College of Social Science, Dongduk Women's University, 60 Hwarang-ro 13gil, Seongbuk-gu, Seoul 02748, South Korea. E-mail: kimwy01@dongduk.ac.kr.

\section{REFERENCES}

Ball, R., \& L. Shivakumar. (2005). Earnings quality in UK private firms: Comparative loss recognition timeliness. Journal of Accounting and Economics, 39(1), 83-128.

Beatty, A., L. Ke, \& K. Petroni. (2002). Earnings management to avoid earnings declines across publicly and privately held banks. The Accounting Review, 77(3), 547-570.

Bhattacharya, N., H. Desai, \& K. Venkataraman. (2007). Earnings quality and information asymmetry: Evidence from trading costs. Working paper.

Biddle, G., G. Hilary, \& R. Verdi. (2009). How does financial reporting quality relate to investment efficiency? Journal of Accounting and Economics, 48(1), 112-131.

Burgstahler, D., L. Hail, \& C. Leuz. (2006). The importance of reporting incentives: Earnings management in European private and public firms. The Accounting Review, 81(5), 983-1016.

Bushman, R., \& A. Smith. (2001). Financial accounting information and corporate governance. Journal of Accounting and Economics, 32(1-3), 237-333.

Chen, F., O. Hope, Q. Li, \& X. Wang. (2011). Financial reporting quality and investment efficiency of private firms in emerging markets. The Accounting Review, 86(4), 1255-1288.

DeAngelo, L. (1981). Auditor size and auditor quality. Journal of Accounting and Economics, 3(3), 183-199.

Dechow, P., \& I. Dichev. (2002). The quality of accruals and earnings: The role of accrual estimations errors. The Accounting Review, 77(Supplement), 35-59.

Francis, J., R. LaFond, P. Olsson, \& K. Schipper. (2004). Cost of equity and earnings attributes. The Accounting Review, 79(4), 967-1010.

Garcia-Teruel, P., P. Martinez-Solano, \& J. Sanchez-Ballesta. (2009). Accruals quality and corporate cash holdings. Accounting \& Finance, 49, 95-115.

Givoly, D., C. Hayn, \& S. Katz. (2010). Does public ownership of equity improve earnings quality? The Accounting and Economics, 39(2), 195-225.

Graham, J., R. Harvey, \& S. Rajgopal. (2005). The economic implications of corporate financial reporting. Journal of Accounting and Economics, 40(1), 3-73.

Hope, O., W. Thomas, \& D. Vyas. (2013). Financial reporting quality of U.S private and public firms. The Accounting Review, 88(5), $1715-1742$.

Jensen, M., \& W. Meckling. (1976). Theory of the firm: Managerial behavior, agency costs and ownership structure. Journal of Financial Economics, 3, 305-360.

Kanodia, C., \& D. Lee. (1998). Investment and disclosure: The disciplinary role of periodic performance reports. Journal of Accounting Research, 36(1), 33-55.

Kim, J., \& C. Yi. (2006). Ownership structure, business group affiliation, listing status, and earnings management: Evidence from Korea. Contemporary Accounting Research, 23(2), 427-464.

Kothari, S., A. Leone, \& C. Wasley. (2005). Performance matched discretionary accrual measures. Journal of Accounting and Economics, 39(1), 163-197.

Kwak, S., \& J. Park. (2010). A comparative analysis on determinants of audit fees of KSE, KOSDAQ and Non-listed firms. Korean Accounting Journal, 19(4), 197-230.

Lambert, R., C. Leuz, \& R. Verrecchia. (2007). Accounting information, disclosure, and the cost of capital. Journal of Accounting Research, 45(2), 385-420.

Leuz, C., D. Nanda, \& P. Wysocki. (2003). Earnings management and investor protection: An international comparison. Journal of Financial Economics, 69(3), 505-527.

Leuz, C., \& R. Verrecchia. (2000). The economic consequences of increased disclosure. Journal of Accounting Research, 38, 91-124.

Liu, M., \& P. Wysocki. (2007). Cross-sectional determinants of information quality proxies and cost of capital measures. Working Paper, MIT.

McNichols, M., \& S. Stubben. (2008). Does earnings management affect firms' investment decisions? The Accounting Review, 83(6), 1571-1603. 
Nam, H. (2010). The effect of listing status and audit quality on earnings quality: Focused on small companies. Korean Accounting Journal, 19(3), 55-82.

Nichols, D., J. Wahlen, \& M. Wieland. (2009). Publicly traded versus privately held: Implications for conditional conservatism in bank accounting. Review of Accounting Studies, 14(1), 88-122.

Reynolds, J., \& J. Francis. (2000). Does size matter? The influence of large clients on office-level auditor reporting decisions. Journal of Accounting and Economics, 30(3), 375-400.

Verdi, R. (2006). Financial reporting quality and investment efficiency. Working paper. 


\section{APPENDIX \\ Variable Descriptions}

\begin{tabular}{|c|c|c|}
\hline \multicolumn{3}{|c|}{ Dependent Variables } \\
\hline InvEff & & $\begin{array}{l}\text { a proxy of investment efficiency, which is measured as the values of residuals from investment forecasting } \\
\text { model, if residuals are greater than } 0 \text {, it is over-investment, and if residuals are less than } 0 \text {, it is under- } \\
\text { investment (under-investment is the absolute values); }\end{array}$ \\
\hline \multicolumn{3}{|c|}{ Explanitory Variables } \\
\hline LIST & $=$ & an indicator variable that if a firm is a listed firm, it takes the value of 1 , and 0 otherwise; \\
\hline$B I G 4$ & $=$ & an indicator variable that if a firm hires a Big 4 audit firm, it takes the value of 1 , and 0 otherwise; \\
\hline \multicolumn{3}{|c|}{ Control Variables } \\
\hline SIZE & $=$ & the natural log of total assets; \\
\hline TANG & $=$ & the ratio of tangible assets, measured as (equipment, plant, and property)/total assets; \\
\hline$S L A C K$ & $=$ & the ratio of cash holding, measured as cash/total assets; \\
\hline OPCYCLE & $=$ & operating cycle: (average accounts receivables/sales) $\times 365+($ average inventory/cost of goods sold) $\times 365$; \\
\hline LOSS & $=$ & an indicator variable that if a firm reports a loss, it takes the value of 1 , and 0 otherwise; \\
\hline$R O A$ & $=$ & return on assets, measured as net income/lagged total assets; \\
\hline Cfo_Sales & $=$ & the ratio of operating cash flow, measured as operating cash flow/sales; \\
\hline$F R \bar{Q} 1$ & $=$ & the absolute residuals of the Kothari et al. (2005) model, multiplied by -1 ; \\
\hline$F R Q 2$ & $=$ & the absolute residuals of the Francis et al. (2005) model, multiplied by -1 ; \\
\hline$F R Q 3$ & $=$ & the absolute residuals of the McNichols and Stubben (2008) model, multiplied by -1 ; \\
\hline Std_Sales & $=$ & the standard deviations of sales in the past three years; \\
\hline Std_Cfo & $=$ & the standard deviations of operating cash flow in the past three years; and \\
\hline$H \overline{H 1}$ & $=$ & the Herfindahl-Hirschman Index for industry concentration. \\
\hline
\end{tabular}

